\title{
Seasonal variation in expression and localization of testicular transforming growth factors TGF- $\beta 1$ and TGF- $\beta 3$ corresponds with spermatogenic activity in roe deer
}

\author{
A Wagener, J Fickel ${ }^{1}$, J Schön ${ }^{2}$, A Fritzenkötter ${ }^{1}$, F Göritz ${ }^{1}$ \\ and $\mathbf{S}$ Blottner ${ }^{\mathbf{1}}$ \\ Institute for Animal Sciences, Humboldt-University, Berlin, Germany \\ ${ }^{1}$ Leibniz-Institute for Zoo and Wildlife Research, PF 601103, D-10252 Berlin, Germany \\ ${ }^{2}$ Institute for Veterinary Biochemistry, Free University, Berlin, Germany \\ (Requests for offprints should be addressed to S Blottner; Email: blottner@izw-berlin.de)
}

\begin{abstract}
Adult roe deer males show hormonally controlled seasonal cycles of testicular growth and involution. Mediation of endocrine signals likely requires variable production of testicular growth factors for regulation of testis function. Here we studied the expression pattern of transforming growth factors (TGFs) $\beta 1$ and $\beta 3$. Total RNA from testis parenchyma was extracted monthly and analysed using quantitative reverse transcriptase PCR. The localization of mRNAs was determined by in situ hybridization, and corresponding proteins were visualized immunohistochemically. Both factors showed different expression levels and different seasonal expression patterns. The TGF- $\beta 1$ mRNA content was up to 45 times higher than that of TGF- $\beta 3$. Compared with its lowest level in May, TGF- $\beta 1$ expression was slightly enhanced during pre-rut (June/
\end{abstract}

July). TGF- $\beta 3$ expression increased 5 -fold from April to June/July and decreased thereafter to its low in December. This corresponded with changing numbers of spermatocytes and round spermatids, in which both TGF- $\beta 3$ mRNA and the protein were mainly localized. The TGF- $\beta 1$ mRNA was found in interstitial cells, mainly during the non-breeding season, but also in spermatocytes and spermatids during activated spermatogenesis. The translation product was localized in few spermatogenic cells only. The results suggest that TGF- $\beta 1$ and $-\beta 3$ are important in regulating seasonal spermatogenesis of roe deer with diverse functions affecting interstitial and spermatogenic cells.

Journal of Endocrinology (2005) 187, 205-215

\section{Introduction}

Mature males of seasonally breeding mammals such as roe deer show synchronized cycles of considerable testicular growth and involution during the transition between breeding and non-breeding periods (for a review see Bronson \& Heidemann 1994). However, the details of underlying mechanisms for the regulation of stimulation as well as inhibition of cell proliferation, development of spermatogenic cells and testosterone production in testes of adult mammals are still unknown.

Testis function is hormonally controlled by the hypothalamic-pituitary-gonadal axis. Receptors for the pituitary-derived gonadotrophins are expressed exclusively on somatic cells, luteinizing hormone on Leydig and follicle-stimulating hormone on Sertoli cells (Zirkin 1993, Sharpe 1994). Therefore, further locally secreted regulators are necessary to modulate cell functions in spermatogenesis (Benahmed 1996, Gnessi et al. 1997) and steroidogenesis (Saez 1994) by autocrine and paracrine actions. Growth factors are such key regulator molecules affecting both cell proliferation and differentiation as well as apoptosis. The transforming growth factor (TGF) $\beta$ family is a family of multifunctional peptides that act by modifying the expression of specific sets of target genes. They regulate a large number of cell functions (Sporn and Roberts 1990, Massague \& Chen 2000) and exert their pleiotropic effects by binding to cell-surface transmembrane receptors (Wrana et al. 1994, Massague \& Chen 2000). TGF- $\beta 1$ and $-\beta 3$ have been reported to affect testicular functions as paracrine/autocrine regulators (for reviews see Gnessi et al. 1997, Lui et al. 2003). Studies in murine testis suggest further that both TGF- $\beta 1$ and $-\beta 3$ gene expression is realized by cell-lineage-specific transcriptional regulation during spermatogenesis (Watrin et al. 1991).

TGF- $\beta 1$ was detected in Leydig and Sertoli cells, in pre-meiotic and meiotic spermatocytes and in round 
spermatids of different species (Teerds \& Dorrington 1993, Gautier et al. 1994, Caussanel et al. 1997, Haagmans et al. 2003). Immunohistochemical studies on human testes showed that TGF- $\beta 1$ protein abounded in Leydig cells, but it was not detectable in seminiferous tubules (Zhang et al. 2004). Thus, distribution and expression of TGF- $\beta 1$ appear to be species-specific.

In germ cells, TGF- $\beta 1$ stimulates DNA synthesis (Hakovirta et al. 1993), whereas in Leydig cells it acts as a potent inhibitor of both DNA synthesis and steroid production (Bebakar et al. 1990, Gautier et al. 1997, LeRoy et al. 1998, Khan et al. 1999). Sertoli cell function can also be affected by TGF- $\beta 1$ in vitro (Esposito et al. 1991, Morera et al. 1992, Grasso et al. 1993). Conversely, germ cells seem to stimulate the expression and secretion of TGF- $\beta 1$ by Sertoli cells (Avallet et al. 1997).

TGF- $\beta 3$ is only localized in spermatogonia and pre-meiotic spermatocytes (Mullaney \& Skinner 1993, Teerds \& Dorrington 1993, Caussanel et al. 1997). In pig, TGF- $\beta 3$ appears to be essential for interactions between pre-meiotic and post-meiotic spermatogenic cells (Caussanel et al. 1997). An effect on post-meiotic cells is assumed from findings in human testes, where TGF- $\beta 3$ and its receptor RI were mainly detected in elongated spermatids. The receptor RII was found in pachytene spermatocytes, and to a much lesser extent in spermatogonia, spermatids and Sertoli cells (Zhang et al. 2004).

The control of testicular cell population size by apoptosis is part of the regulation circuit of spermatogenesis (Blanco-Rodriguez 1998, Sinha-Hikim \& Swerdloff 1999) and has been proposed as a mechanism of testicular regression in several mammals (Furuta et al. 1994, Blottner et al. 1995, Young \& Nelson 2001, Strbenc et al. 2003). A functional correlation to apoptotic processes was demonstrated for both TGF- $\beta 1$ and - $\beta 3$ (Ohta et al. 1996, Olaso et al. 1998a).

To date, the effects of growth factors such as TGF- $\beta$ in the male gonads have been studied mainly in in vitro systems, which yielded rather confusing (Huhtaniemi \& Bartke 2001) and sometimes even contradictory (Teerds \& Dorrington 1993, Gautier et al. 1994) results. Inactivation of testicular genes for several TGF- $\beta$ superfamily members did not cause primary defects in spermatogenesis, suggesting that those genes - at least in mice - are not important in this process (Eddy 1998). However, the role that TGF- $\beta$ s play in spermatogenesis still remains to be determined (Yu et al. 2003).

Thus, to determine the role of TGF- $\beta 1$ and $-\beta 3$ in the regulation of testicular function we measured the time courses of TGF- $\beta 1$ and $-\beta 3$ expression in an in vivo model, the testis of roe deer. Roe deer are seasonal breeders with a short rutting season in summer (late July to early August) and completely arrested spermatogenesis in winter (Short \& Mann 1966, Blottner et al. 1996, Sempéré et al. 1998, Göritz et al. 2003). The continuous transitions between active and inactive state of roe buck testis constitute a valuable model to investigate regulation of testicular activity in adult ruminants without manipulation.

Expression of TGF- $\beta 1$ and $-\beta 3$ was measured by quantitative reverse transcriptase PCR using specially designed primers (Wagener et al. 2000). In addition we localized the mRNAs of both growth factors by in situ hybridization and that of the translation products by immunohistochemical detection. The characterization of seasonally and locally differentiated expression patterns permitted us to elucidate potential functional properties.

\section{Materials and Methods}

\section{Animals and tissues}

For gene-expression analysis, roe deer testis tissue was obtained monthly (except February) by fine-needle biopsies from five free-ranging animals immediately after capture as described by Göritz et al. (2003). The biopsies were immediately put into $20 \mu \mathrm{l}$ TRIzol reagent (GIBCO Life Technologies) and snap-frozen in liquid nitrogen.

The following year we obtained roe deer testis tissue for in situ hybridization and immunohistochemistry by castrating three roe bucks in each of the months of April, June, August and December. After removal testes were dissected into small pieces. Some of them were snap-frozen in liquid nitrogen for preparation of total RNA and some were fixed overnight in Bouin's solution at $4{ }^{\circ} \mathrm{C}$. The fixed pieces were washed extensively in $70 \%$ ethanol, then dehydrated and embedded in paraffin.

The animals were treated in accordance with the German National Animal Welfare Legislation. All procedures were approved by the local Office for the Preservation of Environment and Nature, Eberswalde, Germany.

\section{Reverse transcription reaction}

Total RNA from the biopsies (20-30 mg) was prepared using the High Pure RNA Tissue Kit (Roche Applied Science) as described by Wagener et al. (2003). The gene-specific primers were taken from Wagener et al. (2000). Total RNA from castration material was prepared with peqGOLD TriFast (Peqlab). Isolated RNA was quantified spectrophotometrically at $260 \mathrm{~nm}$. The first cDNA strand was generated from $2 \mu \mathrm{g}$ total RNA using random hexamer primers and Moloney murine leukaemia virus reverse transcriptase (Promega) according to the manufacturer's protocol.

\section{Construction of plasmid standards}

The standards for quantitative PCR were prepared as described by Wagener et al. (2003). Briefly, the PCR fragments were purified with QIAquick PCR Purification 
Kit 250 (Qiagen). All products were cloned into the pGemT vector (Promega), colonies containing plasmids with inserts of TGF- $\beta 1$ and $-\beta 3$, respectively, were grown overnight in liquid LB medium (Sigma) and plasmids were isolated using the PERFECTprep Plasmid DNA Preparation Kit (Peqlab Biotechnologies). The plasmids $(1 \mu \mathrm{g})$ were then digested for $2 \mathrm{~h}$ at $37^{\circ} \mathrm{C}$ with 10 units SpeI (Promega) and after purification (QIAquick PCR Purification Kit 250) the linearized plasmids were quantified spectrophotometrically. Insert identities were verified by sequencing. Standard curve dilutions were prepared, containing $10^{6}, 10^{5}, 10^{4}, 5 \times 10^{3}$ and $10^{3}$ molecules per $5 \mu$ l.

\section{Quantitative PCR}

Either $5 \mu \mathrm{l}$ of the reverse transcription reaction, $5 \mu \mathrm{l}$ of each standard dilution, $5 \mu \mathrm{l}$ of reverse transcription reaction mixture without RNA (negative control 1) or $5 \mu 1$ water (negative control 2) were used in a $25 \mu \mathrm{l} \mathrm{PCR}$ reaction. PCRs were carried out with $2 \times \mathrm{SYBR}$ Green Mastermix (Applied Biosystems) and $160 \mathrm{nM}$ (TGF- $\beta 1$ ) or $200 \mathrm{nM}$ (TGF- $\beta 3$ ) of specific primer. The PCR mixtures were initially denatured for $10 \mathrm{~min}$ at $95^{\circ} \mathrm{C}$ and had a final extension phase of $5 \mathrm{~min}$ at $72^{\circ} \mathrm{C}$. The amplification programme for TGF- $\beta 1$ was 40 cycles of $95^{\circ} \mathrm{C}$ for $30 \mathrm{~s}, 61{ }^{\circ} \mathrm{C}$ for $20 \mathrm{~s}$ and $72{ }^{\circ} \mathrm{C}$ for $40 \mathrm{~s}$, and that for TGF- $\beta 3$ was 40 cyles of $95^{\circ} \mathrm{C}$ for $30 \mathrm{~s}, 63{ }^{\circ} \mathrm{C}$ for $20 \mathrm{~s}$ and $72{ }^{\circ} \mathrm{C}$ for $40 \mathrm{~s}$. The PCRs were performed with a GeneAmp 5700 Sequence Detection System (Applied Biosystems). A melting curve was recorded after completion of the amplification procedure to evaluate the amount of SYBR Green bound to generated primer dimers. The obtained data was analysed using the system-integrated GeneAmp 5700 SDS software (Applied Biosystems).

\section{Probe construction for in situ hybridization}

The PCR fragments of roe deer TGF- $\beta 3$ for in situ hybridization were prepared using primers and PCR conditions as described previously (Wagener et al. 2000). Primers for TGF- $\beta 1$ were $5^{\prime}$-GCTTCAAGTGGACATT AACGGGTTC-3' (forward) and 5'-GGTCCTTCCGG AAGTCAATGTAGAG-3' (reverse). PCR conditions were the same as those for TGF- $\beta 3$ except for annealing at $65{ }^{\circ} \mathrm{C}$.

To generate antisense (probe) and sense RNA (negative control) for the in situ hybridization we used linearized plasmids. For sense RNA $1 \mu \mathrm{g}$ plasmid DNA was digested with 10 units SpeI, and for antisense RNA we digested $1 \mu \mathrm{g}$ plasmid DNA with 10 units NcoI (Stratagene) for $2 \mathrm{~h}$ at $37^{\circ} \mathrm{C}$; digestion success was verified by gel electrophoresis. The linearized plasmids were purified with the QIAquick PCR Purification Kit 250 and quantified spectrophotometrically. Biotinylated sense and antisense
RNAs were generated by in vitro transcription with 40 units T7 RNA polymerase (Fermentas) and 40 units Sp6 RNA polymerase (Roche Applied Science), respectively. Reactions were performed for $2 \mathrm{~h}$ at $37^{\circ} \mathrm{C}$. Buffers were supplemented with ATP, CTP, GTP (1 mM each), UTP (0.65 mM), 0.35 mM Biotin-16-UTP (Biotin RNA Labeling Mix; Roche Applied Science) and 20 units RNasin ribonuclease inhibitor (Promega). DNA was degraded with 20 units DNaseI (Roche Applied Science) for $30 \mathrm{~min}$ at $37^{\circ} \mathrm{C}$. The reaction was stopped with $2 \mu \mathrm{l}$ $0 \cdot 2 \mathrm{M}$ EDTA, $\mathrm{pH} 8 \cdot 0$. RNA was precipitated in ethanol/ sodium acetate. The dried RNA pellet was redissolved in $1 \mathrm{mM}$ sodium citrate, $\mathrm{pH} 6 \cdot 4$, and stored at $-70{ }^{\circ} \mathrm{C}$. RNA content was determined spectrophotometrically and diluted further in hybridization buffer (Innogenex and Maxim Biotech, respectively) for in situ hybridization.

\section{In situ hybridization}

Sections $(3 \mu \mathrm{m})$ of paraffin-embedded testis tissue were mounted onto slides. After deparaffinization and rehydration, proteins were removed from tissue by incubating the slides for $20 \mathrm{~min}$ in $0 \cdot 2 \mathrm{M} \mathrm{HCl}$ followed by 5 min washing in PBS and digestion with proteinase $\mathrm{K}$ (Maxim Biotech and Roche Applied Science, respectively) for $7 \mathrm{~min}$ (TGF- $\beta 1$ ) or $10 \mathrm{~min}$ (TGF- $\beta 3$ ) at $37^{\circ} \mathrm{C}$. The proteinase $\mathrm{K}$ digestion was terminated by a $5 \mathrm{~min}$ incubation period in glycine/PBS (2 mg/ml PBS).

Protocol for TGF- $\boldsymbol{\beta} 1$ Slides were dehydrated and dried at $37^{\circ} \mathrm{C}$ for $5 \mathrm{~min}$. Then the sections were denatured for $2 \mathrm{~min}$ at $80^{\circ} \mathrm{C}$ and immediately chilled on ice for $2 \mathrm{~min}$ as were the biotinylated probes. The sections were incubated overnight with the probe at $40^{\circ} \mathrm{C}$ in a humidified chamber. Afterwards they were washed at hybridization temperature in $2 \times \mathrm{SSC}$ for $30 \mathrm{~min}$, in $1 \times \mathrm{SSC}$ for $15 \mathrm{~min}$ and in $0.5 \times \mathrm{SSC}$ at room temperature. The proteins were blocked with blocking buffer (Maxim Biotech) for $30 \mathrm{~min}$ at $37^{\circ} \mathrm{C}$ followed by incubation with alkaline phosphatase-conjugated streptavidin (Maxim Biotech) for $30 \mathrm{~min}$ at $37^{\circ} \mathrm{C}$. After $10 \mathrm{~min}$ washing in washing buffer (Maxim Biotech) the sections were treated with substrate 5-bromo-4-chloroindol-3-yl phosphate (BCIP)/Nitro Blue Tetrazolium (NBT; Maxim Biotech) for $10 \mathrm{~min}$ at room temperature. Thereafter they were washed in double-distilled water $(3 \times 3 \mathrm{~min})$ and briefly counterstained with eosine. Negative controls were hybridized with biotinylated sense RNA.

Protocol for TGF- $\beta 3$ The RNA was denatured by incubation in $2 \times \mathrm{SSC}$ for $15 \mathrm{~min}$ at $70{ }^{\circ} \mathrm{C}$. Slides were then post-fixed in $2 \%$ paraformaldehyde/PBS $(\mathrm{v} / \mathrm{v})$. After two 5 -min washing steps in $2 \times \mathrm{PBS}$ and then PBS, slides were immersed for $20 \mathrm{~s}$ in $20 \%$ acetic acid at $4{ }^{\circ} \mathrm{C}$ and for $2 \mathrm{~min}$ in $2 \% \mathrm{H}_{2} \mathrm{O}_{2} /$ methanol $(\mathrm{v} / \mathrm{v})$ at $4{ }^{\circ} \mathrm{C}$ and washed again ( $5 \mathrm{~min}$, PBS at room temperature). The 
sections were dehydrated and air-dried for $30 \mathrm{~min}$. Pre-hybridizations were carried out in probe-free hybridization buffer (Innogenex) for $1.5 \mathrm{~h}$ at $42{ }^{\circ} \mathrm{C}$. The biotinylated antisense RNA probe $(2 \mathrm{ng} / \mu \mathrm{l}$ in hybridization buffer) and sections were denatured separately for $2 \mathrm{~min}$ at $80{ }^{\circ} \mathrm{C}$, and immediately chilled on ice. The sections then underwent overnight incubation with the probe at $42{ }^{\circ} \mathrm{C}$. Afterwards they were washed at hybridization temperature in $50 \%$ formamide $/ 2 \times \mathrm{SSC}(\mathrm{v} / \mathrm{v})$ for $30 \mathrm{~min}$, in $2 \times \mathrm{SSC}$ for $15 \mathrm{~min}$, at room temperature in $1 \times \mathrm{SSC}$ and in $0.5 \times \mathrm{SSC}$ for $10 \mathrm{~min}$ each. Sections were then rinsed with and put into PBS/Tween $20(0 \cdot 1 \%(\mathrm{v} / \mathrm{v})$ for $5 \mathrm{~min})$. An incubation followed with the peroxidase (POD)streptavidin conjugate $(0.5$ units in PBS; Roche Applied Sciences) for $30 \mathrm{~min}$ at room temperature. After a $3 \mathrm{~min}$ washing step in PBS containing $0 \cdot 1 \%$ Tween $20(\mathrm{v} / \mathrm{v})$ the peroxidase reaction was triggered by adding the substrate 3,3'-diaminobenzidine (Roche Applied Sciences) for 5-10 min under visual control, after which sections were counterstained briefly with haemalum. Negative controls were hybridized with biotinylated sense RNA.

\section{Western blot analysis}

To verify the specificity of the binding of TGF- $\beta 1$ and - $\beta 3$ antibodies a Western blot was performed. A small piece of testis parenchyma was cooled in liquid nitrogen and crushed in a mortar. Powdered tissue was mixed up in RIPA buffer and underwent lysis on ice for $30 \mathrm{~min}$. Insoluble constituents were pelleted by repeated centrifugation at $12480 \mathrm{~g}$ for $15 \mathrm{~min}$. The protein content of the lysate was $30 \mathrm{mg} / \mathrm{ml}$. Proteins were separated by SDS/ PAGE (Mini Protean II; Bio-Rad) and then transferred to a methanol pre-wetted PVDF membrane (Bio-Rad) by semi-dry blotting using Towbin transfer buffer. Membranes were rinsed with double-distilled water and then immersed overnight in Amersham blocking solution (part of the ECL Advance Western Blotting Detection Kit; Amersham Biosciences) at $4{ }^{\circ} \mathrm{C}$. Immunodetection was performed with $0.2 \mu \mathrm{g} / \mathrm{ml}$ anti-TGF- $\beta 1$ or $-\beta 3$ (Santa Cruz Biotechnology) and goat anti-rabbit POD (Sigma Diagnostics) 1:50.000 in blocking solution. Membranes were rinsed intensely in PBS/Tween $20(0 \cdot 1 \%, \mathrm{v} / \mathrm{v})$ in between and after antibody incubations. Antigens were detected by chemiluminescence (ECL Advance Western Blotting Detection Kit).

\section{Immunostaining of TGF- $\beta 1$ and $-\beta 3$}

Paraffin sections $(2 \mu \mathrm{m})$ were cut with a microtome and mounted on superfrost slides (Roth). Sections were deparaffinized, rehydrated and washed in PBS. For detection of TGF- $\beta 1$ an antigen retrieval was performed by boiling slides in citrate buffer, $\mathrm{pH} 6$, for 2 min followed by a 20 -min cooling period. Slides were then washed again in PBS. To block endogenous peroxidase activity slides were
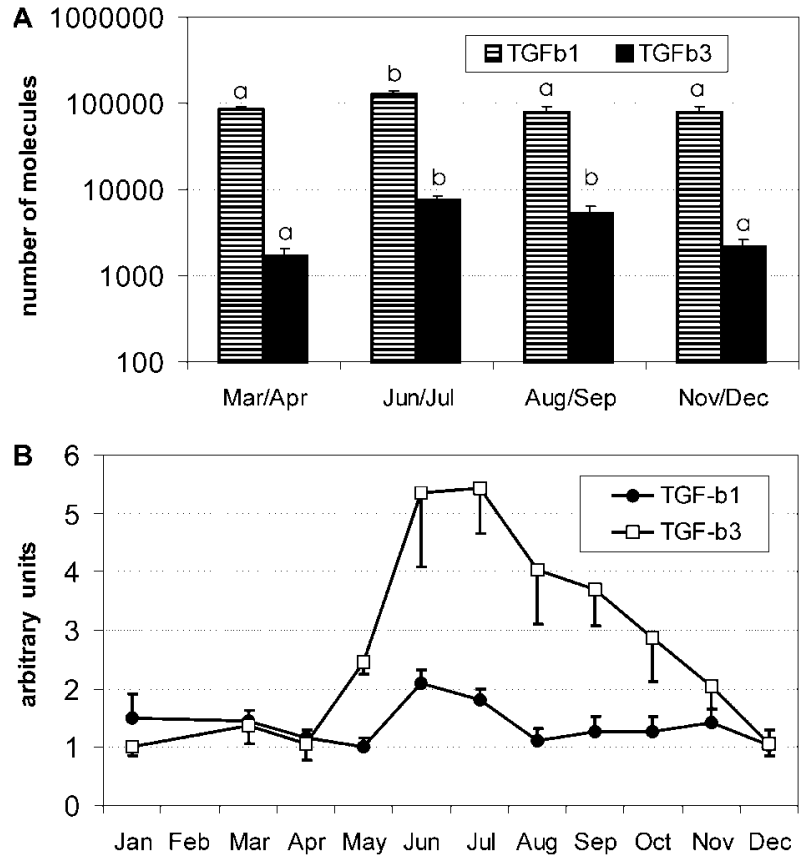

Figure 1 (A) Absolute expression level of TGF- $\beta 1$ and $-\beta 3$ mRNAs during the four main phases of the reproductive cycle: activated testis growth (March/April, phase I), pre-rutting period (June/July, phase II), late rutting period including beginning testicular involution (August/September, phase III) and spermatogenesis arrest (November/December, phase IV). Values represent the number of RNA molecules in 10 ng total RNA (means \pm SEM) measured by quantitative PCR with a DNA standard. The scale of the $y$ axis is logarithmic. Differences between columns with different letters are significant (contrast analysis). (B) Relative expression levels of TGF- $\beta 1$ and $-\beta 3$ throughout the year. The seasonal variation of expression level was normalized (arbitrary units) by dividing each value by the lowest amount of mRNA (TGF- $\beta 1$, May $=1$; TGF- $\beta 3$, January $=1$ ). The data points represent estimations in monthly collected testis biopsies from five roe bucks. The seasonal variation of the means is significant for both growth factors $(P<0.01$ and $P<0 \cdot 001$; ANOVA).

incubated twice (15 min each) in $\mathrm{H}_{2} \mathrm{O}_{2}$ /methanol (3\%, $\mathrm{v} / \mathrm{v}$ ) and washed again in PBS. To block non-specific binding sites slides were then incubated for $1 \mathrm{~h}$ at $37^{\circ} \mathrm{C}$ in PBS containing $0 \cdot 1 \%$ Tween 20 and 5\% BSA. Afterwards the blocking solution was carefully flushed from the sections. The primary antibodies, polyclonal rabbit antihuman TGF- $\beta 1$ and $-\beta 3$, were diluted to either $0 \cdot 1 \mu \mathrm{g} / \mathrm{ml}$ (TGF- $\beta 1$ ) or $1 \mu \mathrm{g} / \mathrm{ml}$ (TGF- $\beta 3$ ), added carefully to the slides and incubated overnight at $4{ }^{\circ} \mathrm{C}$. After intensive washing steps $(3 \times 15 \mathrm{~min}$, PBS/Tween $0 \cdot 1 \%$; with shaking) bound primary antibodies were marked by a dextran polymer carrying secondary antibody and horseradish peroxidase molecules (EnVision Dako; $30 \mathrm{~min}$ at room temperature). Diaminobenzidine (DAB plus; DAKO; for 1-4 min under visual control) was used as the chromogenic substrate. In negative controls the primary antibody was substituted with rabbit IgG. 

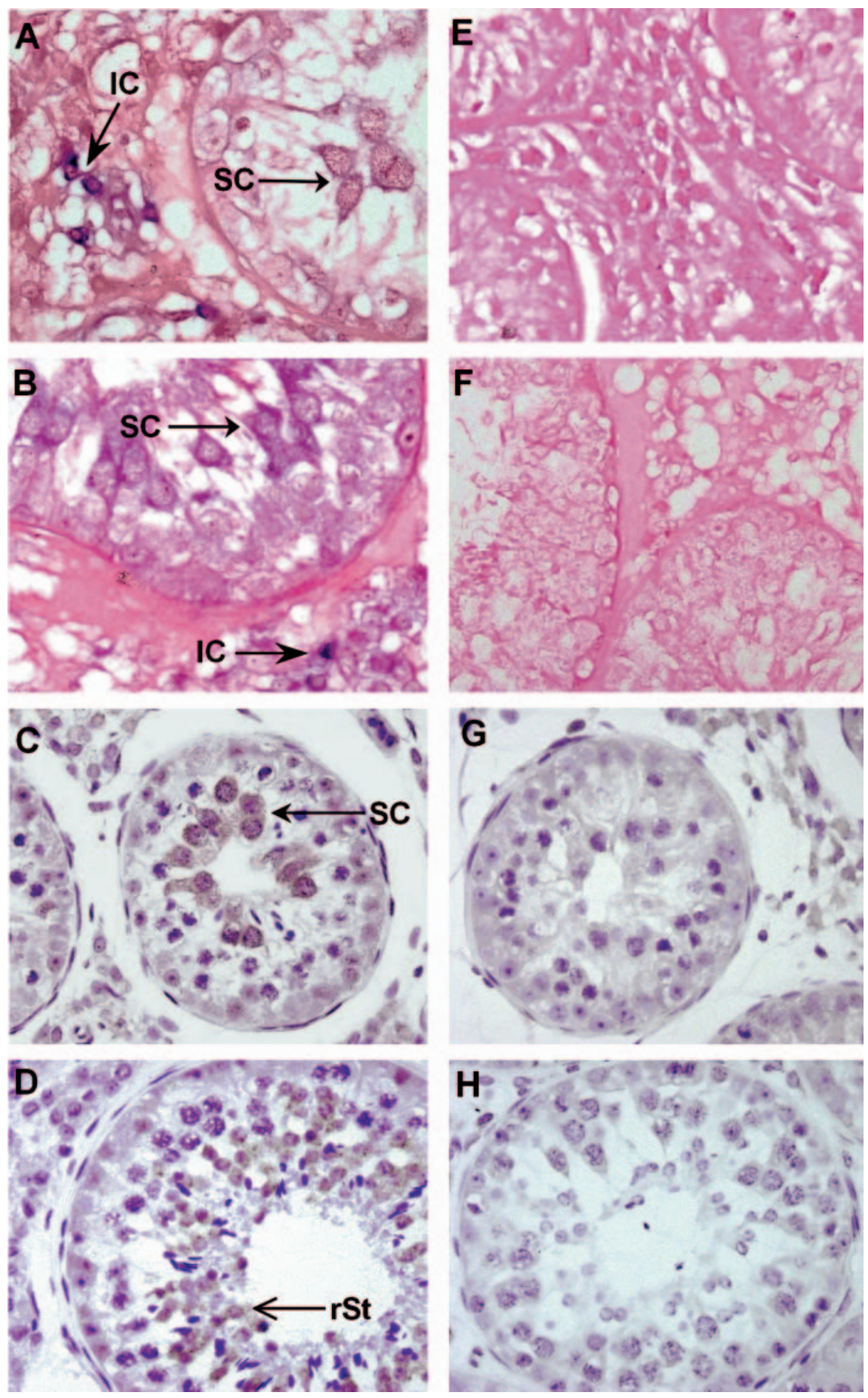

Figure 2 Localization of TGF- $\beta 1$ and $-\beta 3$ mRNA in roe deer testis in April (A, C) and June (B, D), detected by in situ hybridization. Positive staining for TGF- $\beta 1$ mRNA (blue colour in $A$ and $B$; counterstaining with eosine) and for TGF- $\beta 3$ mRNA (brown colour in $C$ and D; counterstaining with haemalum) is indicated by arrows in spermatocytes (SC), round spermatids ( $\mathrm{rSt}$ ) and interstitial cells (IC). Negative controls $(\mathrm{E}-\mathrm{H})$ were hybridized with sense RNA. 
The number of TGF- $\beta 1$-immunopositive cells within the tubules was very low. For evaluation of seasonal differences, stained cells were counted (magnification $400 \times)$ in a total of 100 circular tubule sections of randomly chosen vision fields from sections of three animals per month.

\section{Statistical analyses}

For both growth factors, each animal and each month the total number of mRNA molecules per 10 ng RNA was calculated and means \pm S.E.M. for the five animals were determined. TGF- $\beta 1$ and $-\beta 3$ expression was analysed using Kendall's coefficient of concordance and contrast analysis. The Kendall test was applied to test for the parallel annual course of annual expression curves for the five individuals. Such parallelism is a prerequisite for reliable average values. A contrast analysis was performed to compare the four main phases of the roe deer reproductive cycle. These four phases are activated testis growth (March/April, phase I), pre-rutting period (June/July, phase II), late rutting period including onset of testicular involution (August/September, phase III) and arrest of spermatogenesis (November/December, phase IV). The determination of these phases is based on morphological, cytological and endocrinological data from roe deer testis (Blottner et al. 1996, Roelants et al. 2002, Göritz et al. 2003). Consequently, the contrast analysis includes the pairwise comparisons among all phases. For comparison purposes, the seasonal variation of expression levels was standardized as relative expression by dividing each value by the lowest number of mRNA molecules. The repeated measurements ANOVA was applied to determine the variation among monthly means. All calculations were performed using the SPSS 9.0 statistical software package (SPSS, Chicago, IL, USA). The significance level was set to $5 \%$.

\section{Results}

\section{Seasonal expression of TGF- $\beta 1$ and $-\beta 3$}

mRNAs for TGF- $\beta 1$ and $-\beta 3$ were detected at all time points and in all testes examined, thus both were expressed throughout the entire year. Based on the monthly standard curves $10 \mathrm{ng}$ total RNA were calculated to contain between 75000 and 125000 molecules of TGF- $\beta 1$ mRNA and between 1600 and 7500 molecules of TGF- $\beta 3$ mRNA (Fig. 1A). Comparison of the mRNA contents of both factors for each of the four seasonal phases showed that the TGF- $\beta 1 \mathrm{mRNA}$ level was approximately 15 times higher than that of TGF- $\beta 3$ during both early and late rutting periods (phases II and III) and up to 45 times higher during the other two periods (phases I and IV).
The diagram of relative expression levels showed for both factors a peak of expression during the pre-rut (phase II). But comparing relative expression levels of both TGF- $\beta$ s throughout the year showed that TGF- $\beta 1$ expression varied much less than TGF- $\beta 3$ expression (Fig. 1B). The annual course of the five individual expression curves was regarded as parallel for both TGF- $\beta$ s (Kendall's test; $P=0.007$ and $P<0.001$, respectively). According to the contrast analysis with the combined values of the four main phases of the roe deer reproductive cycle, it was only during the pre-rutting period (phase II) that TGF- $\beta 1$ was significantly more highly expressed than in other phases (II/I, $P=0.003$; II/III, $P=0 \cdot 004$; II $/ \mathrm{IV}, P=0 \cdot 025)$. Expression values from the other phases did not differ significantly (Fig. 1A). TGF- $\beta 3$ mRNA expression steeply increased between May and June, remained elevated until July and decreased subsequently continuously until December. It reached its lowest level in the phase of suppressed spermatogenesis and remained low until April. Its relative expression in the summer months (June to September) was about four to five times as high as in the period from November to April. The comparison between the combined bimonthly values of the four main phases revealed that the raised TGF- $\beta 3 \mathrm{mRNA}$ levels in the early and late rutting phases (phases I and II) were significantly different $(P<0 \cdot 01$ and $P<0 \cdot 05$, respectively) from the other two phases.

\section{Cellular localization of TGF- $\beta 1$ and $-\beta 3 m R N A$ expression}

TGF- $\beta 1$ mRNA was localized in interstitial cells, spermatocytes and round spermatids (Fig. 2). In the interstitium, TGF- $\beta 1$ was found more frequently when interstitial cell density was high; that is, during non-breeding seasons, especially during the growth phase (April; Fig. 2A). Due to the lack of cell-specific markers and the fact that in both periods interstitial cells are not fully differentiated, a more detailed cell-type characterization was not possible. In spermatocytes and spermatids, TGF- $\beta 1$ RNA was found during all periods in which these cells were present: in spermatocytes from activated growth phase (April) to the rut in August and in round spermatids in June (Fig. 2B) and August, respectively.

TGF- $\beta 3$ mRNA was found in germ cells only (Fig. 2C and D). From April to August it was detected in premeiotic and meiotic spermatocytes and during June and August additionally in early round spermatids. During the inhibited spermatogenesis in December no in situ hybridization staining of any remaining cell type was possible.

\section{Cellular localization of TGF- $\beta 1$ and $-\beta 3$ peptides}

Western analysis of protein extracts of roe deer testicular tissue samples and immunohistochemistry demonstrated the presence of immunoreactive proteins for both growth factors (Fig. 3). The three bands obtained with the rabbit 

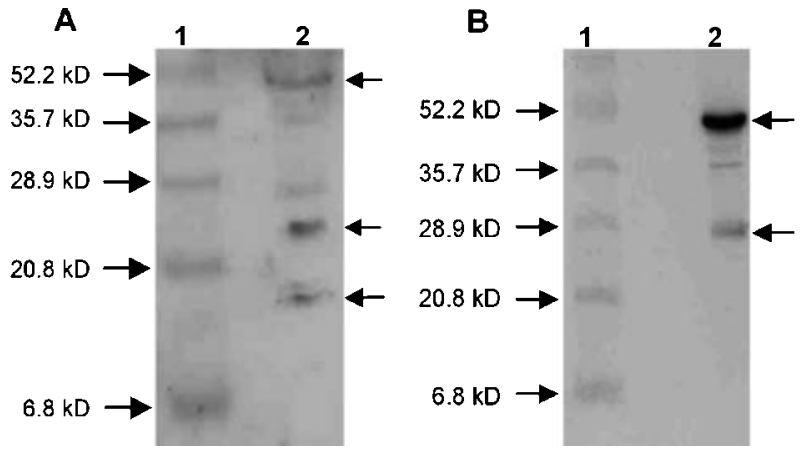

Figure 3 Western analysis and immunodetection of TGF- $\beta 1$ (A) and TGF- $\beta 3$ (B) in testicular tissue lysates (lanes 1, marker; lanes 2, tissue extract). Three bands obtained with the rabbit anti-human TGF- $\beta 1$ antibody indicate the presence of precursor protein, processed protein and monomer of the processed protein. The distinct band recognized by the rabbit anti-human TGF- $\beta 3$ antibody at $40 \mathrm{kDa}$ corresponds to the molecular mass of the precursor protein (panel B). The weak band at $25 \mathrm{kDa}$ represents the processed protein.

anti-human TGF- $\beta 1$ antibody indicated the presence of precursor protein, of the processed, biological active homodimeric protein and of the monomer of the processed peptides (Fig. 3A). The rabbit anti-human TGF- $\beta 3$ antibody provided a distinct band at $40 \mathrm{kDa}$, which corresponds to the molecular mass of the precursor protein (Fig. 3B). The weak band at $25 \mathrm{kDa}$ represents the processed protein.

Both translation products were detected in the seminiferous tubules only. Few spermatogenic cells (spermatogonia and spermatocytes) were labelled for TGF- $\beta 1$ peptide in all studied months (Fig. 4A and B) and several of these cells showed morphological signs of degeneration (pycnotic nuclei, nuclear dilatation, cell fragmentation). The average frequency of labelled cells was higher in June and August (0.55 and 0.36 cells per tubule cross-section) than in April or December $(0.06$ and $<0.01$ cells per tubule cross-section).

TGF- $\beta 3$ was visible predominantly in primary and secondary spermatocytes shortly before and during the meiotic divisions and in round spermatids (Fig. 4C and D). Sertoli cells were also immunostained, but with lower intensity. All immunopositive cells were observed from April to August only.

All findings regarding the seasonally changing cellular localization and frequency of cells stained for TGF- $\beta 1$ and $-\beta 3$ (both mRNA and protein) are summarized in a scheme (Fig. 5).

\section{Discussion}

TGFs $\beta 1$ and $\beta 3$, investigated in roe deer testis, were expressed at different levels, had different expression courses throughout the year and differed in terms of their localization in somatic and spermatogenic cells. This is consistent with both their involvement in the regulation of seasonal spermatogenesis and their most likely diverse functions.

The seasonal variation in the expression of growth factor mRNA may generally be caused by changes in the frequency of producing cells and/or expression activity of these cells. Any effort to explain the results of expression measurements has to consider that the ultimately determined amount of specific mRNA results from seasonally changing proportions of expressing cells within the used standardized quantities of tissue.

The TGF- $\beta 1$ mRNA was found in the interstitium. The frequency of positively stained cells was approximately correlated with proportions of interstitial cells within the parenchyma; that is, high in spring and winter. Additionally, it occurred in definite stages of spermatocytes and spermatids during activated spermatogenesis in summer. Thus, the declining proportion of interstitial cells expressing TGF- $\beta 1 \mathrm{mRNA}$ seems to be compensated - at least partly - by increasing proportions of expressing spermatogenic cells during testis growth, and vice versa.

The high amount of testicular TGF- $\beta 1$ molecules throughout the year suggests that this growth factor is mainly involved in the regulation of general testicular processes during all seasons and additionally of spermatogenesis during the breeding season. An inhibitory effect of TGF- $\beta 1$ on steroidogenesis in Leydig cells is conceivable, because TGF- $\beta 1$ is mainly expressed in interstitial cells during non-breeding periods (December and April) when testosterone concentration is low (Sempéré et al. 1998, Roelants et al. 2002) and Leydig cells are structurally and functionally dedifferentiated (Short \& Mann 1966, Hombach-Klonisch et al. 2004). These results are in concordance with the inhibitory effect of TGF- $\beta 1$ on steroidogenesis and DNA synthesis in Leydig cells in other species (Bebakar et al. 1990, Gautier et al. 1997, LeRoy et al. 1998, Khan et al. 1999). Correspondingly, both the TGF- $\beta 1$ protein and its mRNA were found in cultured porcine Leydig cells (Avallet et al. 1994). However, the effect on steroidogenesis in roe deer remains unclear because we could not detect the TGF- $\beta 1$ peptides in the interstitial compartment. This result could have been caused by an altered epitope of the intracellular precursor after fixation, an intertubular distribution in concentrations below the limit of detection by the available antibody or an inaccessibility of the secreted, active peptide by binding to target cells.

A potential role of TGF- $\beta 1$ in meiotic processes can be derived from the short-term increase of TGF- $\beta 1 \mathrm{mRNA}$ during intensified sperm production. This corresponds with a detectably higher frequency of TGF- $\beta 1$ peptide containing spermatogenic cells in June and August compared with the other months studied. This is also in accordance with its detection in spermatogenic cells of 

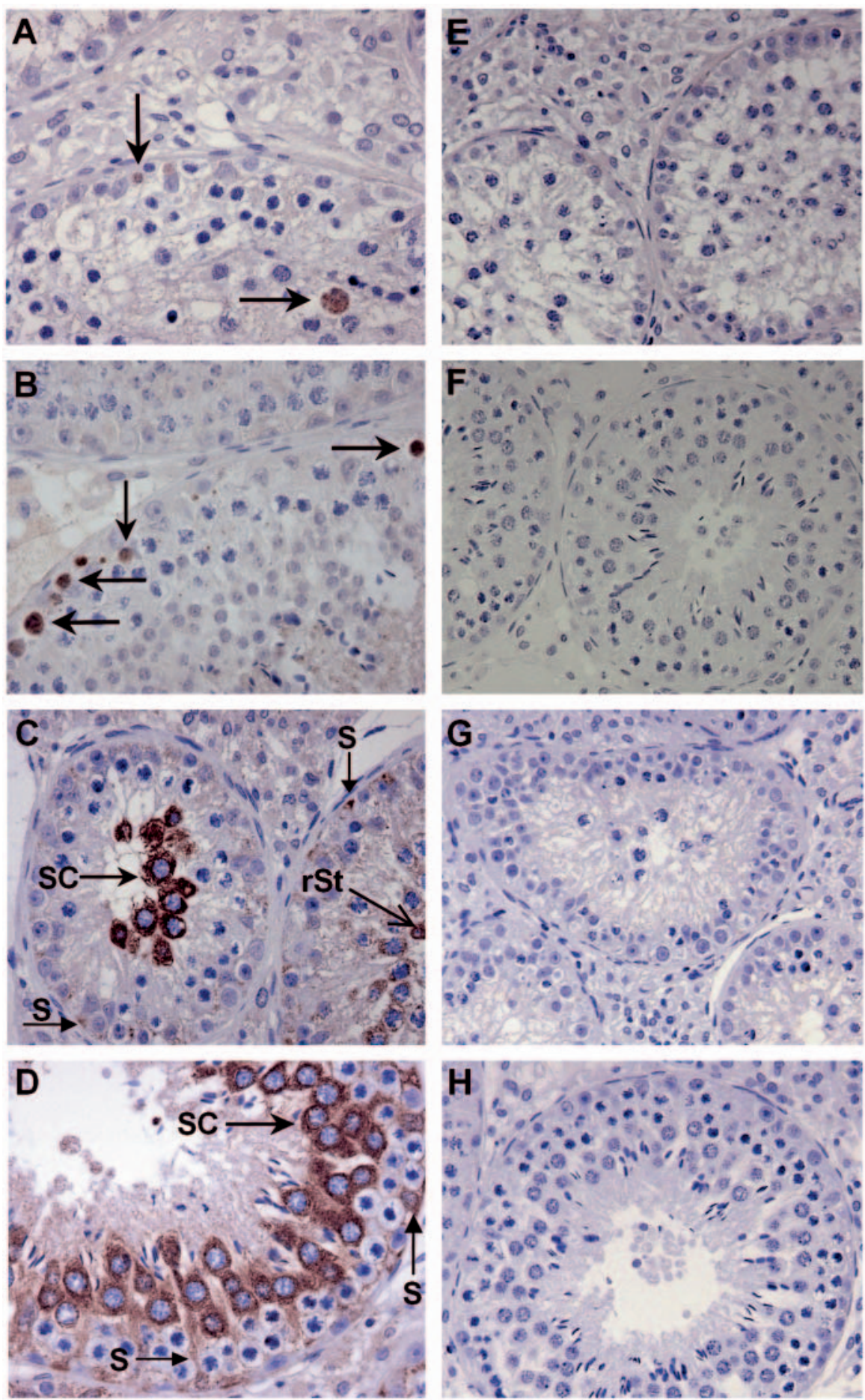

Figure 4 Localization of TGF- $\beta 1$ and TGF- $\beta 3$ in roe deer testis in April (A, C) and June (B, D) detected by immunohistochemical labelling. Positive staining (brown colour) is indicated by arrows in few spermatogenic cells for TGF- $\beta 1$ (A and B) and in spermatocytes (SC), round spermatids (rSt) and Sertoli cells (S) for TGF- $\beta 3$ (C and D). Negative controls ( $E-H)$ were incubated with rabbit IgG. The counterstain was haemalum. 
April

testis recrudescence

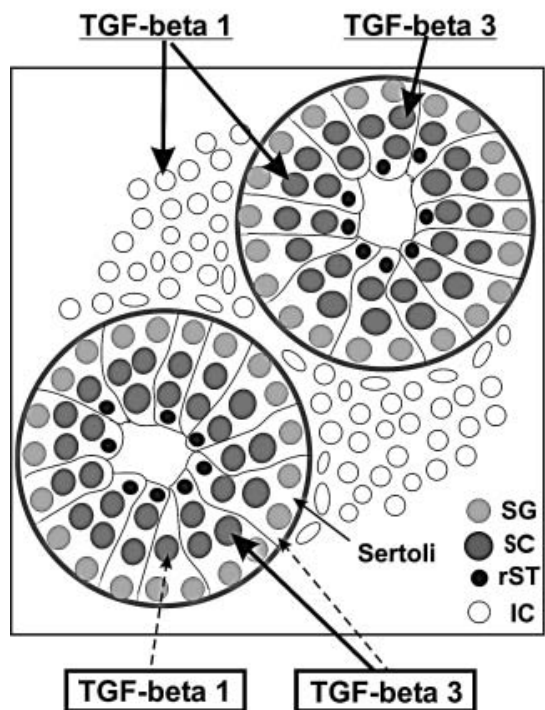

June-August activated spermatogenesis

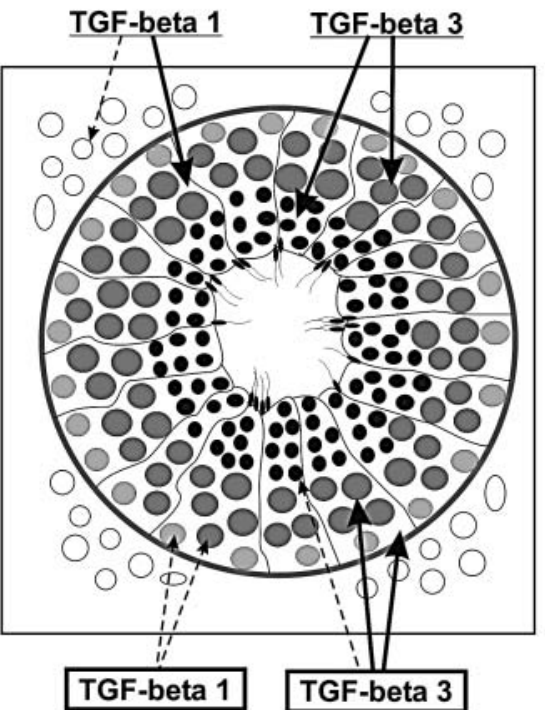

December arrested spermatogenesis

Figure 5 Scheme of seasonally changing expression of TGF- $\beta 1$ and $-\beta 3$ in the cell types of roe deer testis (mRNAs are shown at the top, proteins at the bottom). The frequency of labelled cells is indicated by bold or thin arrows, respectively. SG, spermatogonia; SC, spermatocytes; rST, round spermatids; IC, interstitial cells. Sertoli cells are only adumbrated between the spermatogenic cells. Cell numbers and tubular diameters reflect seasonally changing morphometric quantities and dimensions.

non-seasonal breeders (Teerds \& Dorrington 1993, Gautier et al. 1994, Caussanel et al. 1997, Haagmans et al. 2003). However, the lack of TGF- $\beta 1$ in seminiferous tubules of human testis (Zhang et al. 2004) suggests species-specific differences.

In rat germ cells, TGF- $\beta 1$ stimulates DNA synthesis in vitro (Hakovirta et al. 1993). Although studied in other mammals, the respective TGF- $\beta$ receptors were found in spermatocytes and spermatids (Caussanel et al. 1997, Olaso et al. 1998b, Zhang et al. 2004); thus their expression in roe deer germ cells is conceivable. In addition, an effect by TGF- $\beta 1$ and $-\beta 3$ on Sertoli cell activity, as described for other species (Esposito et al. 1991, Grasso et al. 1993, Panthou et al. 1994, Lui et al. 2003) also cannot be excluded.

TGF- $\beta 3$ mRNA was found exclusively in spermatogenic cells. Its expression level was lower than that of TGF- $\beta 1$, but was five-fold enhanced during the highly activated spermatogenesis in June and July (phase II), reflecting the distinctly raised proportion of expressing cells. The increased expression of both TGF- $\beta 3$ mRNA and its translation product in summer coincides with the generation of spermatids and spermatozoa, respectively (Blottner et al. 1996, Göritz et al. 2003, Schön et al. 2004). This matches the periods in which Sertoli cells are morphologically and functionally the most differentiated (Russell 1993). Thus, in adult roe deer testis TGF- $\beta 3$ seems to be involved in the regulation of specific spermatogenic cell-type development rather than in the onset of spermatogenesis, as discussed for pubertal rat (Mullaney \& Skinner 1993). The frequency of immunopositive cells corresponds with the high expression of precursor as seen in the Western blot and suggests the intracellular storage of TGF- $\beta 3$ in its inactive form. In contrast to roe deer, immunolocalization of TGF- $\beta 3$ in human testis demonstrated its preponderant occurrence in Leydig cells, but it was also seen in elongated spermatids (Zhang et al. 2004).

The rise of mRNAs of both TGF- $\beta$ s during the early rutting phase (phase II) coincides also with a boosted apoptosis in testicular tissue (Blottner \& Schön 2005). The apoptosis rate in seminiferous tubules of roe deer was very low; the most apoptotic cells were found in June (caspase-3 detection) or between August and October (terminal deoxynucleotidyl transferase-mediated dUTP nick-end labelling (TUNEL) assay; Blottner \& Schön 2005). This indicates a stimulation of apoptosis following the intensified proliferation. Most probably apoptosis is initiated early to eliminate both defective germ cells and those that would not reach maturity until the end of rut. The occurrence of the TGF- $\beta 1$ protein in some spermatocytes with morphological signs of degeneration suggests the involvement of this growth factor in apoptotic control and corresponds with reports demonstrating a functional correlation with apoptotic processes for TGF- $\beta 1$ (Ohta et al. 1996, Olaso et al. 1998a). In our study no indications were found for the involvement of TGF- $\beta 3$ in the induction of apoptosis. 
The localization of mRNAs and their translation products (Fig. 5) suggest that both TGF- $\beta$ s have autocrine as well as paracrine actions. However, the discussion of clear causal relationships between the appearance of growth factors and the function of different testicular cell types requires the detection of the respective receptors on target cells. In general, discrepancies between the site of gene expression and protein accumulation could result from secretion of the active peptide and its binding on target cells in distant testicular regions or compartments. Only the measurement of TGF- $\beta$ gene expression, protein production and interactions with the specific receptors will allow a conclusive evaluation of autocrine and paracrine actions in the complex communication network of somatic and spermatogenic cells.

In conclusion, this study demonstrates, to our knowledge for the first time, the seasonal expression of TGF- $\beta 1$ and $-\beta 3$ in roe deer testis. The different levels and seasonal dependencies of their expression suggest that TGF- $\beta$ s have different functions in testicular cells. Both factors, and in particular TGF- $\beta 3$, appear to be necessary for the development and/or differentiation of germ cells. TGF- $\beta 1$ gene expression was additionally detected in interstitial cells, but without a corresponding localization of the translation product. Stimulating effects on apoptotic processes during the period of activated spermatogenesis were observed only for TGF- $\beta 1$ by means of morphological indications in few cells. Further studies, including the seasonal expression of TGF- $\beta$ receptors, are necessary to characterize the functions of TGF- $\beta$ s in the regulation of spermatogenesis and its seasonal changes.

\section{Acknowledgements}

This study was supported by a scholarship of the Humboldt University Berlin (to A W) and by a DFG grant (B1 319/7-1). We thank Dr Jürgen Streich for his help in performing the statistical analysis and Christiane Franz for technical assistance.

\section{References}

Avallet O, Vigier M, Leduque P, Dubois PM \& Saez JM 1994 Expression and regulation of transforming growth factor-beta1 messenger ribonucleic acid and protein in cultured porcine Leydig and Sertoli cells. Endocrinology 134 2079-2087.

Avallet O, Gomez E, Vigier M, Jegou B \& Saez JM 1997 Sertoli cell-germ cell interactions and TGF beta 1 expression and secretion in vitro. Biochemical and Biophysical Research Communications 238 905-909.

Bebakar WM, Honour JW, Foster D, Liu YL \& Jacobs HS 1990 Regulation of testicular function by insulin and transforming growth factor- $\beta$. Steroids $\mathbf{5 5} 266-270$.

Benahmed M 1996 Growth factors and cytokines in the testis. In Male Infertility, pp 55-97. Ed FH Comhaire. London: Chapman and Hall

Blanco-Rodriguez J 1998 A matter of death and life: the significance of germ cell death during spermatogenesis. International Journal of Andrology 21 236-248.
Blottner S \& Schön J 2005 Minimal activity in both proliferation and apoptosis of interstitial cells indicates seasonally persisting Leydig cell population in roe deer. Cell and Tissue Research DOI $10 \cdot 1007 / \mathrm{s} 00441-005-1132-6$

Blottner S, Hingst O \& Meyer HHD 1995 Inverse relationship between testicular proliferation and apoptosis in mammalian seasonal breeders. Theriogenology 44 320-328.

Blottner S, Hingst O \& Meyer HHD 1996 Seasonal spermatogenesis and testosterone production in roe deer (Capreolus capreolus). Journal of Reproduction and Fertility 108 299-305.

Bronson FH \& Heidemann PD 1994 Seasonal regulation of reproduction in mammals. In The Physiology of Reproduction, edn 2, pp 541-583. Eds E Knobil \& JD Neill. New York: Ravens Press.

Caussanel V, Tabone E, Hendrick JC, Dacheux F \& Benahmed M 1997 Cellular distribution of transforming growth factor- $\beta$ 's 1,2 and 3 and their types I and II receptors during postnatal development and spermatogenesis in the boar testis. Biology of Reproduction 56 357-367.

Eddy EM 1998 Regulation of gene expression during spermatogenesis. Seminars in Cell and Development Biology 9 451-457.

Esposito G, Keramidas M, Mauduit C, Feige JJ, Morera AM \& Benahmed M 1991 Direct regulating effect of transforming growth factor- $\beta 1$ on lactate production in cultured porcine Sertoli cells. Endocrinology 128 1441-1449.

Furuta I, Porkka-Heiskanen T, Scarbrough K, Tapanainen J, Turek FW \& Hsueh AJW 1994 Photoperiod regulates testis cell apoptosis in djungarian hamsters. Biology of Reproduction 51 1315-1321.

Gautier C, Levacher C, Avallet O, Vigier M, Rouiller-Fabre V, Lecerf L, Saez JM \& Habert R 1994 Immunohistochemical localization of transforming growth factor- $\beta 1$ in fetal and neonatal rat testis. Molecular and Cellular Endocrinology 99 55-61.

Gautier C, Levacher C, Saez JM \& Habert R 1997 Transforming growth factor- $\beta 1$ inhibits steroidogenesis in dispersed fetal testicular cells in culture. Molecular and Cellular Endocrinology 131 21-30.

Gnessi L, Fabbri A \& Spera G 1997 Gonadal peptides as mediators of development and functional control of the testis: an integrated system with hormones and local environment. Endocrine Reviews $\mathbf{1 8}$ 541-609.

Göritz F, Quest M, Wagener A, Faßbender M, Broich A, Hildebrandt TB, Hofmann RR \& Blottner S 2003 Seasonal timing of sperm production in roe deer: interrelationship between chnages in ejaculate parameters, morphology and function of testis and accessory glands. Theriogenology 59 1487-1502.

Grasso P, Reichert LE Jr, Sporn MB \& Santa-Coloma TA 1993 Transforming growth factor- $\beta 1$ modulates calcium metabolism in Sertoli cells. Endocrinology 132 1745-1749.

Haagmans BL, Hoogerbrugge JW, Themmen AP \& Teerds KJ 2003 Rat testicular germ cells and Sertoli cells release different types of bioactive transforming growth factor beta in vitro. Reproductive Biology and Endocrinology 13.

Hakovirta H, Kaipia A, Soder O \& Parvinen M 1993 Effects of activin- $A$, inhibin- $A$ and transforming growth factor- $\beta 1$ on stage-specific deoxyribonucleic acid synthesis during rat seminiferous epithelial cycle. Endocrinology 133 1664-1668.

Hombach-Klonisch S, Schön J, Kehlen A, Blottner S \& Klonisch T 2004 Seasonal expression of INSL3 and Lgr8/INSL3 receptor transcripts indicates variable differentiation of Leydig cells in the roe deer testis. Biology of Reproduction 71 1079-1087.

Huhtaniemi I \& Bartke A 2001 Perspective: male reproduction. Endocrinology 142 2178-2183.

Khan SA, Mirsafian M, Howdeshall K \& Dorrington JH 1999 Transforming growth factor- $\beta$ inhibits DNA synthesis in immature rat leydig cells in vitro. Molecular and Cellular Endocrinology 148 21-28.

Le Roy C, Leduque P, Yuan Li J, Saez JM \& Langlois D 1998 Antisense oligonucleotide targeting the transforming growth factor-beta1 increases expression of specific genes and functions of Leydig cells. European Journal of Biochemistry 257 506-514. 
Lui WY, Lee WM \& Cheng CY 2003 TGF-betas: their role in testicular function and Sertoli cell tight junction dynamics. International Journal of Andrology 26 147-160.

Massague J \& Chen Y-G 2000 Controlling TGF- $\beta$ signaling. Genes and Development 14 627-644.

Morera AM, Esposito G, Ghiglieri C, Chauvin MA, Hartmann DJ \& Benahmed M 1992 Transforming growth factor- $\beta 1$ inhibits gonadotropin action in cultured porcine Sertoli cells. Endocrinology $130831-836$

Mullaney BP \& Skinner MK 1993 Transforming growth factor- $\beta$ $(\beta 1, \beta 2$ and $\beta 3$ ) gene expression and action during pubertal development of the seminiferous tubule: potential role at the onset of spermatogenesis. Molecular Endocrinology 7 67-76.

Ohta Y, Nishikawa A, Fukazawa Y, Urushitani H, Matsuzawa A, Nishina Y \& Iguchi T 1996 Apoptosis in adult mouse testis induced by experimental cryptorchidism. Acta Anatomica 175 195-204.

Olaso R, Pairault C, Boulogne B, Durand P \& Habert R 1998a Transforming growth factor- $\beta 1$ and $\beta 2$ reduce the number of gonocytes by increasing apoptosis. Endocrinology 139 733-740.

Olaso R, Pairault C \& Habert R 1998 bxpression of type 1 and 2 receptor for transforming growth factor- $\beta$ in the adult rat testis. Histochemistry and Cell Biology 110 613-618.

Panthou P, Barbey P, Thiebot B \& Bocquet J 1994 Effects of transforming growth factor- $\beta 1$, interleukin- $1 \alpha$ and interleukin- 6 on rat Sertoli cell proteoglycan synthesis. Biochemistry and Molecular Biology International 34 603-612.

Roelants H, Schneider F, Göritz F, Streich J \& Blottner S 2002 Seasonal changes of spermatogonial proliferation in roe deer, demonstrated by flow cytometric analysis of c-kit receptor, in relation to follicle-stimulating hormone, luteinizing hormone and testosterone. Biology of Reproduction 66 305-312.

Russell LD 1993 Sertoli cell structure and function in seasonally breeding mammals. In The Sertoli Cell, pp 350-364. Eds LD Russell \& MD Griswold. Clearwater, FL: Cache River Press.

Saez JM 1994 Leydig cells: endocrine, paracrine and autocrine regulation. Endocrine Reviews 15 574-626.

Schön J, Göritz F, Streich J \& Blottner S 2004 Histological organization of roe deer testis throughout the seasonal cycle: variable and constant components of tubular and interstitial compartment. Anatomy and Embryology 208 151-159.

Sempéré AJ, Mauget R \& Mauget C 1998 Reproductive physiology of roe deer. In The European Roe Deer: the Biology of Success, pp 161-188. Eds R Andersen, P Duncan \& JDC Linnel. Oslo: Scandinavian University Press.

Sharpe M 1994 Regulation of spermatogenesis. In The Physiology of Reproduction, edn 2, pp 1363-1434. Eds E Knobil \& JD Neill. New York: Ravens Press.
Short RV \& Mann T 1966 The sexual cycle of a seasonally breeding mammal, the roe buck (Capreolus capreolus). Journal of Reproduction and Fertility 12 337-351.

Sinha-Hikim AP \& Swerdloff RS 1999 Hormonal and genetic control of germ cell apoptosis in the testis. Reviews on Reproduction 4 38-47.

Sporn MB \& Roberts AB 1990 The transforming growth factor-beta: past, present and future. Annals of the New York Academy of Sciences $5931-4$.

Strbenc M, Fazarinc G, Bavdek SV \& Pogacnik A 2003 Apoptosis and proliferation during seasonal testis regression in the brown hare (Lepus europaeus L.) Anatomia Histologia Embryologia 32 48-53.

Teerds KJ \& Dorrington JH 1993 Localisation of transforming growth factor- $\beta 1$ and $-\beta 2$ during testicular development in the rat. Biology of Reproduction $\mathbf{4 8}$ 40-45.

Wagener A, Blottner S, Göritz F \& Fickel J 2000 Detection of growth factors in the testis of roe deer (Capreolus capreolus). Animal Reproduction Science 64 65-75.

Wagener A, Blottner S, Göritz F, Streich WJ \& Fickel J 2003 Differential changes in expression of a and b FGF, IGF 1 and 2, and TGF- $\alpha$ during seasonal growth and involution of roe deer testis. Growth Factors 21 95-102.

Watrin F, Scotto L, Assoian RK \& Wolgemuth DJ 1991 Cell lineage specificity of expression of the murine transforming growth factor beta 3 and transforming growth factor beta 1 genes. Cell Growth and Differentiation 2 77-83.

Wrana JL, Attisano L, Wieser R, Ventura F \& Massague J 1994 Mechanism of activation of the TGF-beta receptor. Nature $\mathbf{3 7 0}$ 341-347.

Young KA \& Nelson RJ 2001 Mediation of seasonal testicular regression by apoptosis Reproduction 122 677-685.

Yu ZR, Guo R, Ge Y, Ma J, Guan J, Li S, Sun X, Xue S \& Han D 2003 Gene expression profiles in different stages of mouse spermatogenic cells during spermatogenesis. Biology of Reproduction $6937-47$.

Zhang YQ, He XZ, Zhang JS, Wang RA, Zhou J \& Xu RJ 2004 Stage-specific localization of transforming growth factor $\beta 1$ and $\beta 3$ and their receptors during spermatogenesis in men. Asian Journal of Andrology 6 105-109.

Zirkin BR 1993 Regulation of spermatogenesis in the adult mammal: gonadotropins and androgens. In: Cell and Molecular Biology of the Testis, pp 166-188. Eds C Desjardins \& LL Ewing. New York: Oxford University Press.

Received 8 July 2005

Accepted 25 August 2005

Made available online as an Accepted Preprint 12 September 2005 
